\title{
Itseorganisoivan kartan ryvästys paljastaa maatilojen kannattavuusprofiilit
}

\author{
Mika Sulkava ${ }^{1}$, Anne-Mari Sepponen ${ }^{2)}$, Maria Yli-Heikkiläa ${ }^{3)}$ ja Arto Latukka ${ }^{4)}$ \\ ${ }^{1)}$ MTT, Taloustutkimus, Latokartanonkaari 9, 00790 Helsinki, mika.sulkava(at)mtt.fi \\ ${ }^{2)}$ MTT, Taloustutkimus, Kampusranta 9 C, 60320 Seinäjoki, anne-mari.sepponen(at)mtt.fi \\ ${ }^{3)}$ MTT, Taloustutkimus, Animale, Tietotie, 31600 Jokioinen, maria.yli-heikkila(at)mtt.fi \\ ${ }^{4)}$ MTT, Taloustutkimus, Latokartanonkaari 9, 00790 Helsinki, arto.latukka(at)mtt.fi
}

\section{TIIVISTELMÄ}

Suomen maa- ja puutarhatilojen kannattavuutta ja muita taloudellisia tekijöitä on tässä työssä analysoitu itseorganisoivan kartan ryvästykseen perustuen. Itseorganisoiva kartta on akateemikko Teuvo Kohosen 1980-luvulla kehittämä neuroverkkomenetelmä, jonka avulla suuri, moniulotteinen havaintoaineisto voidaan esittää havainnollisena kaksiulotteisena karttana. Menetelmän avulla aineistoja voidaan visualisoida tehokkaasti, ja visualisointien avulla aineistosta voidaan löytää useiden muuttujien välisiä epälineaarisia yhteyksiä. Tämän lisäksi itseorganisoivan kartan pohjalta aineistoja voidaan ryvästää eli klusteroida, ja tällä tavoin jakaa aineisto toisistaan poikkeaviin ryhmiin, jotka ovat kuitenkin sisäisesti suhteellisen homogeenisia.

Tutkimuksessamme analysoimme kannattavuuskirjanpitoaineistoa vuodelta 2010, ja löysimme useita kiinnostavia yhteyksiä tarkkailtavien taloudellisten muuttujien välillä. Ryvästyksen avulla muodostimme erilaisten maatilojen taloudellisia profiileja. Löydösten merkityksellisyys varmistettiin tilastollisten testien avulla.

Jaoimme kannattavuuskirjanpitotilat itseorganisoivan kartan ryvästyksen avulla kymmeneen seuraavanlaiseen ryhmään. 1. Suuret tilat, joilla on suuri viljelyala, matala pääoman tuotto ja kannattavuuskerroin sekä korkea velkarasite. 2. Keskikokoiset tilat, joilla on erittäin suuri velkarasite sekä matala omavaraisuusaste ja kannattavuuskerroin. 3. Tilat, joilla on hyvin pieni viljelyala, pieni tase, kokoluokkaan suhteutettuna paljon työtunteja, hyvin matala kokonaispääoman tuotto ja kannattavuuskerroin. Kasvihuonetilojen osuus tässä ryhmässä on suhteellisen suuri. 4. Suuret tilat, joilla on suuri viljelyala, korkea pääoman tuotto ja kannattavuuskerroin sekä keskitason velkarasite. 5. Keskikokoiset, korkeariskiset tilat, joilla on suuri viljelyala ja erityisen suuri vuokrattu viljelyala. Muut nautakarjatilat ovat tässä ryhmässä keskimääräistä paremmin edustettuina. 6. Keskikokoiset, pieniriskiset tilat, joilla on pieni velkarasite, erittäin korkea omavaraisuusaste, ja jotka ovat lähes pelkästään lypsykarjatiloja. 7. Pienet, matalariskiset tilat, jotka ovat useimmiten viljanviljelytiloja, ja joilla on hyvin pieni viljelyala ja velkarasite, pieni tase, hyvin vähän työtunteja ja eläimiä sekä hyvin matala kannattavuuskerroin. 8. Keskikokoiset, erittäin kannattavat tilat, joiden viljelyala on suurempi ja työtuntien määrä pienempi kuin muilla vastaavankokoisten tilojen ryhmillä. 9. Pienet tilat, joiden kannattavuuskerroin on korkea, ja jotka ovat suhteellisen harvoin lypsykarjatiloja, mutta melko usein viljanviljelytiloja. 10. Pienet korkeariskiset tilat, joiden kannattavuus on keskimääräinen ja vieraan pääoman takaisinmaksuaika melko lyhyt.

Asiasanat: itseorganisoiva kartta, ryvästys, maatalous, kannattavuus, kirjanpito 


\section{Johdanto}

Maatilayritysten taloudellinen kannattavuus on erittäin tärkeää, koska se mahdollistaa yritysten liiketoiminnan pitkällä aikavälillä ja siten myös niiden toiminnan osana vakaata ruokaketjua. Maatilojen kannattavuus on vaihdellut runsaasti viime vuosina (Rantala ja Tauriainen, 2013). Tämä saattaa hankaloittaa viljelijöiden tulevaisuuden suunnittelua.

Tässä artikkelissa käytetään itseorganisoivaa karttaa (self-organizing map, SOM) maa- ja puutarhatalousyritysten taloudellisen aineiston analysointiin. Itseorganisoiva kartta on tehokas neuroverkkomenetelmä suurten tietoaineistojen tutkimiseen. Tässä työssä analysoitavan aineiston on kerännyt Maa- ja elintarviketalouden tutkimuskeskus (MTT) kannattavuuskirjanpitotiloista koostuvasta otoksesta. Aineisto on myös monien Suomen maataloutta kuvaavien lukujen lähteenä MTT:n Taloustohtori-verkkopalvelussa (http://www.mtt.fi/taloustohtori). Työn tavoitteena on löytää uusia kiinnostavia yhteyksiä aineistossa olevien taloudellisten muuttujien välillä.

Itseorganisoivaa karttaa on aiemmin käytetty menestyksekkäästi monissa maataloustieteen ongelmissa (katso esim. Sulkava ym., 2013). Kuitenkaan maatalouden taloudellisen toiminnan analyysissa menetelmää ei ole aiemmin juurikaan sovellettu. Tässä artikkelissa esitellään edellä viitatun artikkelin keskeisimpiä tuloksia.

Artikkelin loppuosan rakenne on seuraavanlainen: seuraavassa osassa esitellään kannattavuuskirjanpitoaineisto sekä SOM:n ja SOM-pohjaisen ryvästyksen perusperiaatteet, kolmannessa osassa esitetään SOM-analyysin tulokset ja viimeisessä osassa johtopäätökset.

\section{Aineisto ja menetelmät}

\section{Kannattavuuskirjanpitoaineisto}

Suomen maa- ja puutarhatalousyritysten kannattavuutta kuvaavat luvut lasketaan vuosittain MTT:n kannattavuuskirjanpidon perusteella. Nämä kannattavuusluvut kuvaavat noin 60000 yrityksen keskimääräisiä tuloksia. Tilojen kannattavuutta tarkkaillaan noin 1000 tilan otoksen avulla. Tässä työssä käytetään vuoden 2010 aineistoa. Kyseisenä vuonna kannattavuuskirjanpitotiloja oli 940 kappaletta. Kannattavuuskirjanpidon alkuperäisenä tavoitteena on ollut edustaa 40000 Suomen suurinta tilaa, ja tämän vuoksi otoksessa on melko vähän pieniä tiloja.

Kannattavuuskirjanpitoaineistoon kerätään tiloilta tuhansia muuttujia. Tätä työtä varten valittiin tarkasteltavaksi huomattavasti pienempi määrä muuttujia. Tavoitteena oli valita sellaisia muuttujia, jotka antavat monipuolisen kuvan maatilayritysten taloudellisesta tilanteesta - erityisesti kannattavuudesta ja maksuvalmiudesta. Tarkasteluun otettiin seuraavat muuttujat: taloudellinen koko, viljelyala, tuet, kokonaistuotto, yrittäjän voitto, eläinyksiköt, korkovaatimus, omavaraisuusaste, kokonaispääoman tuotto, yrittäjätulo, kannattavuuskerroin, oman pääoman tuotto, työtuntiansio, tase, oma pääoma, korkoprosentti, palkka- ja korkovaatimukset, vieraan pääoman takaisinmaksuaika, velkarasite, työtunnit, vuokrattu viljelyala, tuotantosuunta ja tukialue.

Oman työvoiman palkkakustannus on laskettu $14 €$ :n tuntipalkalla vuonna 2010. Korkokustannus on laskettu tilakohtaisen korkoprosentin avulla, joka on riskittömän korkotason ja tilakohtaisen riskipreemion summa. Riskipreemio riippuu omavaraisuusasteen, kokonaispääoman tuoton ja velkarasitteen ajallisesta vaihtelusta. Kun yrittäjätulosta vähennetään oman työvoiman ja pääoman tuottovaatimukset saadaan yrittäjän voitto. Kannattavuuskerroin saadaan jakamalla yrittäjätulo palkka- ja korkovaatimusten summalla. Kun kannattavuuskerroin on 1, kaikki tuotantokustannukset on saatu katettua ja yrittäjän voitto on 0 .

Suomen maatalous on EU-säännöksiin perustuen jaettu 14 taloudelliseen tilakokoluokkaan ja 10 tuotantosuuntaan. Lisäksi Suomi on jaettu seitsemään tukialueeseen. Taulukossa 1 on esitetty tuotantosuunnat ja tukialueet etelästä (A) pohjoiseen (C4). Tukialueiden maantieteelliset rajat näkyvät kuvassa 1.

Tässä työssä käytetään pinta-alayksikkönä hehtaaria. Eläinyksiköt on määritelty niin, että lypsylehmä vastaa yhtä eläinyksikköä ja muille kotieläimille on olemassa omat kertoimensa siten, että pienet eläimet vastaavat alle yhtä eläinyksikköä. Muuttujien laskentaa on esittänyt tarkemmin Latukka (1998) sekä Community Committee for the Farm Accountancy Data Network (2009). 
Taulukko 1. Tuotantosuuntien ja tukialueiden numerointi.

\begin{tabular}{lll} 
& Tuotantosuunta & Tukialue \\
\hline 1 & Viljanviljely & A \\
2 & Muu kasvinviljely & B \\
3 & Kasvihuonetilat & C1 \\
4 & Avomaatilat & C2 \\
5 & Lypsykarja & C2P \\
6 & Muu nautakarja & C3 \\
7 & Lammas- ja vuohitilat & C4 \\
8 & Sikatalous & \\
9 & Siipikarjatalous & \\
10 & Sekamuotoinen tuotanto &
\end{tabular}

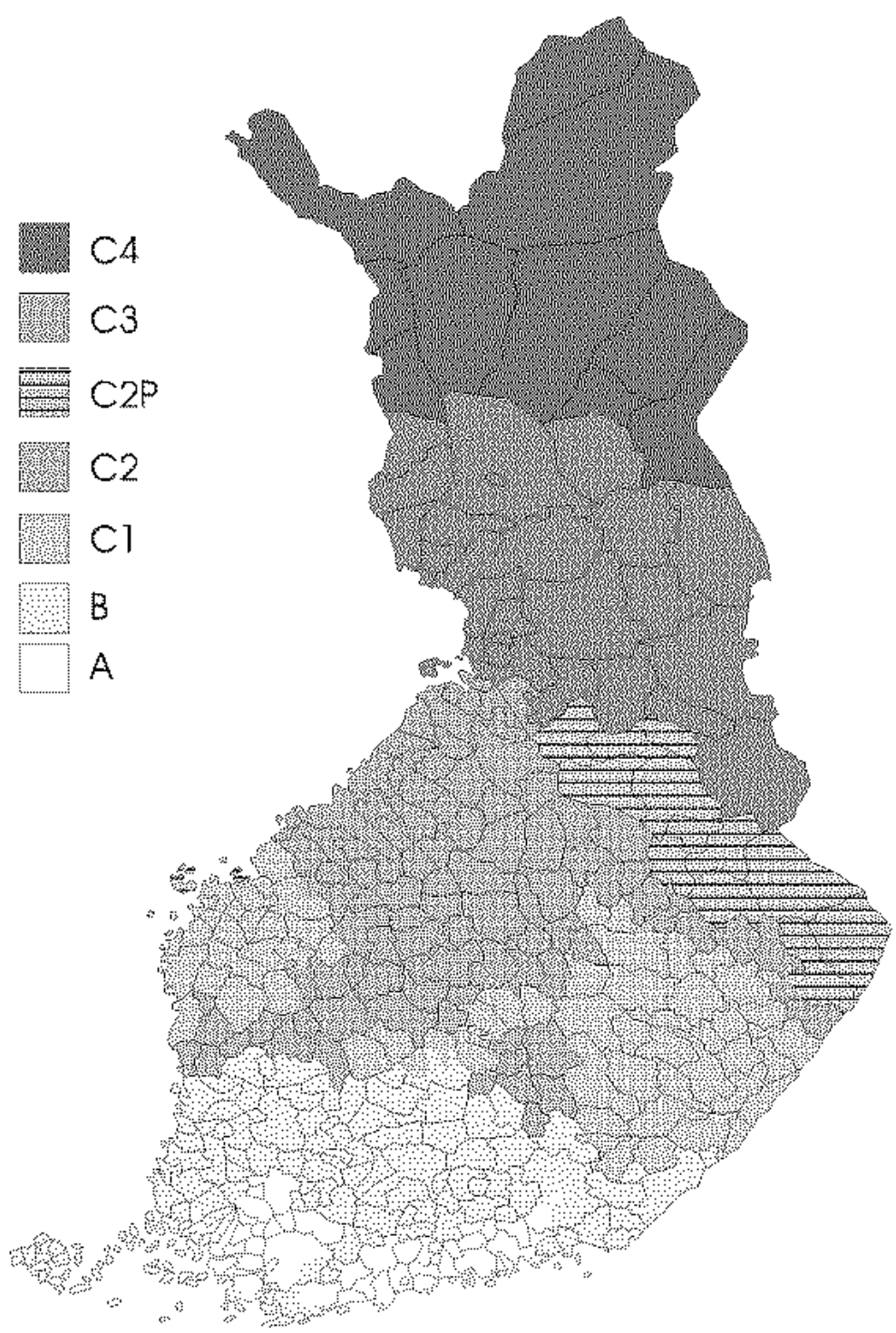

Kuva 1. Kartta Suomen tukialueista. Kuvan lähde: Maaseutuvirasto (Mavi). 


\section{Itseorganisoiva kartta}

Itseorganisoiva kartta eli SOM (Kohonen, 2001) on tehokas menetelmä eksploratiiviseen dataanalyysiin, eli aineistoon tutustumiseen tilanteissa, joissa tutkittavan aineiston rakenteesta ei ole kovin tarkkaa etukäteistietoa. SOM on yksi monista neuroverkkomenetelmistä. Neuroverkkomenetelmät ovat aivojen toimintaa jäljitteleviä tietokoneohjelmia, jotka oppivat automaattisesti niille syötetyn aineiston piirteitä. SOM oppii sille opetetun aineiston rakenteen ja projisoi sen tasopinnalle, josta on helppo piirtää aineistoa esittäviä kuvia. Itseorganisoivaa karttaa on viime vuosikymmenten aikana käytetty menestyksekkäästi monissa sovelluksissa (Kaski ym., 1998; Oja ym., 2003).

SOM koostuu säännöllisestä, yleensä kaksiulotteisesta karttayksiköiden hilasta. Kaksiulotteisella hilalla olevan sijaintinsa lisäksi jokaisella karttayksiköllä on moniulotteinen prototyyppivektori alkuperäisen aineiston muodostamassa avaruudessa. Tällä tavoin SOM määrittelee epälineaarisen projektion moniulotteisesta aineistoavaruudesta kaksiulotteiselle hilalle. SOM opetetaan edustamaan alkuperäistä aineistoa mukauttamalla prototyyppivektoreita aineiston jakauman mukaisesti. Alkuperäiset havainnot projisoidaan hilalle lähimmän prototyyppivektorin avulla.

Opetuksen seurauksena aineistossa toisiaan lähellä olevat havainnot ovat tyypillisesti lähellä toisiaan myös kaksiulotteisella hilalla. Itseorganisoivan kartan opetusta voidaan verrata joustavan verkon venyttämiseen aineiston jakauman muotoiseksi moniulotteisessa avaruudessa. SOM:n avulla muodostettua esitystä voidaan käyttää informaation visualisointiin, ryvästykseen ja aineistoon tutustumiseen. Tässä työssä SOM:n opetus ja analysointi toteutettiin käyttäen MATLAB-ohjelmiston SOM Toolbox -lisäosaa (www.cis.hut.fi/projects/somtoolbox/package/docs2/somtoolbox.html).

SOM:sta voi tehdä visualisointeja mm. käyttäen komponenttitasoja ja U-matriisia. Yksi komponenttitaso näyttää yhden muuttujan arvot värisävyinä karttahilalla. U-matriisi (unified distance matrix, Ultsch ja Siemon, 1990) taas näyttää väreinä hilalla karttayksikön sisäiset sekä hilalla vierekkäisten karttayksiköiden väliset etäisyydet.

Ryvästyksessä eli klusteroinnissa tavoitteena on löytää aineistosta ryhmiä, jotka ovat sisäisesti homogeenisia, ja jotka eroavat toisista ryhmistä. U-matriisia käytetään usein SOM:n visuaaliseen ryvästykseen. Huonona puolena ihmisten käsityönä tekemässä visuaalisessa ryvästyksessä on valintojen subjektiivisuus, minkä seurauksena eri ihmisten tekemien ryvästysten lopputulokset eivät välttämättä ole samanlaiset. Tämän takia on järkevää käyttää automaattista ryvästysalgoritmia ryhmien etsimiseen. Tässä työssä ryvästykseen käytettiin Vesannon ja Sulkavan (2002) kehittämää menetelmää.

\section{Tulokset ja tulosten tarkastelu}

Kannattavuuskirjanpitotiloja kuvaava taloudellinen kartta muodostettiin SOM:n avulla. Opetuksessa ei käytetty tukialue- ja tuotantosuuntamuuttujia, koska kyseiset muuttujat eivät kuvasta tilojen taloudellista tilannetta.

Kuvassa 2 on esitetty kannattavuuskirjanpitoaineistolla opetetun SOM:n U-matriisi ja komponenttitasot. Ryvästyksellä saadut tilaryhmät sekä muuttujat, joita ei käytetty kartan opetuksessa, on esitetty kuvassa 3. Jotkin tuotantosuunnat eivät ole lainkaan näkyvissä tuotantosuuntaa vastaavalla komponenttitasolla. Tämä johtuu osittain siitä, että kyseiset tuotantosuunnat ovat suhteellisen harvinaisia sekä kirjanpitoaineistossa että koko Suomen maataloudessa.

U-matriisi viittaa siihen suuntaan, että aineistossa saattaa olla ryppäistä rakennetta. Tämän vuoksi aineisto ryvästettiin edellisessä osassa mainitulla automaattisella menetelmällä. Lisäksi huomattiin, että kartan kummassakin yläkulmassa ja vasemmassa alakulmassa on tiloja, joille on tyypillistä taloudellisten muuttujien äärimmäiset arvot.

Erilaisia taloudellisia tilatyyppejä on helppo löytää komponenttitasojen avulla. Esimerkiksi kartan vasemman yläkulman tilojen tase, oma pääoma, viljelyala, vuokrattu viljelyala ja eläinyksiköiden määrä ovat hyvin suuria. Sulkava ym. (2012) ovat aiemmin analysoineet aineistoa yksityiskohtaisemmin komponenttitasojen avulla.

Kuvassa 3 näkyy ryvästyksen lopputulos SOM:n hilalla. Ryhmien lukumäärä valittiin siten, että ryhmät olisivat suhteellisen suuria, mutta homogeenisia. Tällä perusteella päädyttiin jakamaan aineisto 10 ryhmään. Ryhmien välisten erojen merkitsevyyttä on tutkittu tilastollisilla testeillä, ja suurin osa eroista osoittautui tilastollisesti merkitseviksi (Sulkava ym., 2013). Edellä mainitussa työssä on lisäksi tarkasteltu perusteellisemmin ryhmien sisäistä vaihtelua sekä kannattavuusprofiileja mm. laatikkokuvioiden avulla, mihin tässä työssä ei tilarajoitusten takia ole mahdollisuutta. Seuraavissa kappaleissa esitellään löydettyjen ryhmien keskeisimmät ominaisuudet. 


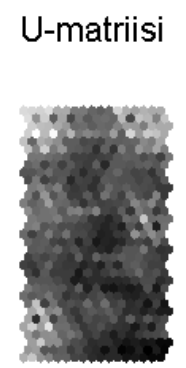

kokonaistuotto

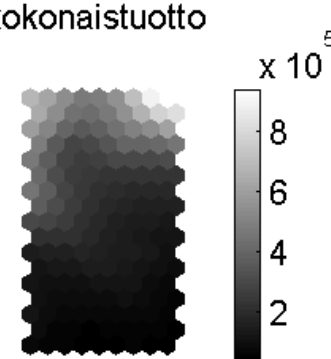

omavaraisuusaste

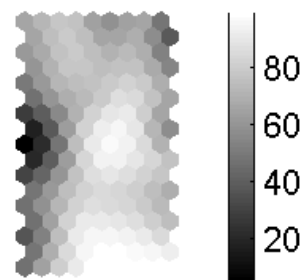

oman pääoman tuotto

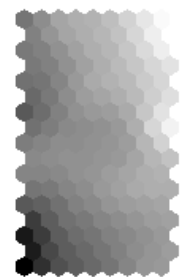

korkoprosentti

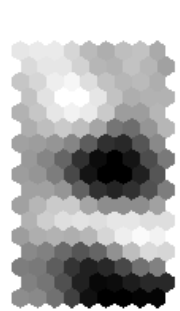

työtunnit

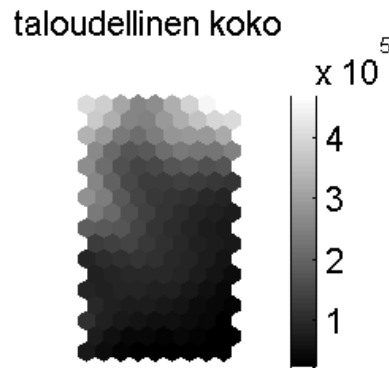

yrittäjän voitto

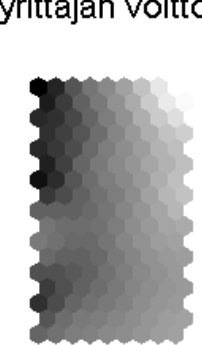

$\times 10^{4}$

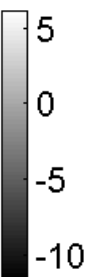

kokonaispääoman tuotto
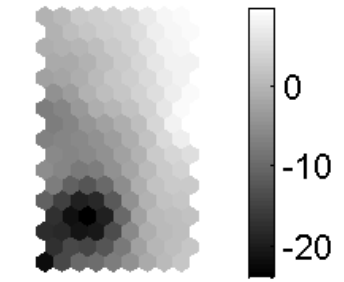

työtuntiansio
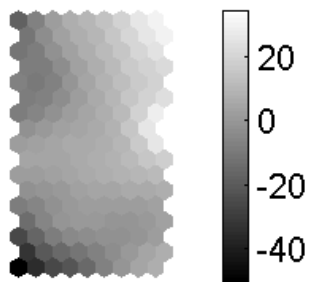

palkka- ja korkovaatim
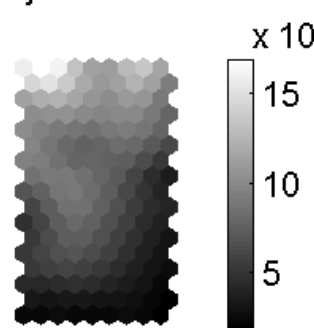

vuokrattu vieljelyala

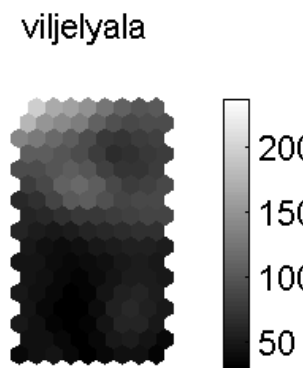

eläinyksiköt

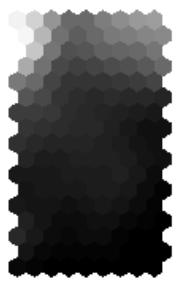

yrittäjätulo

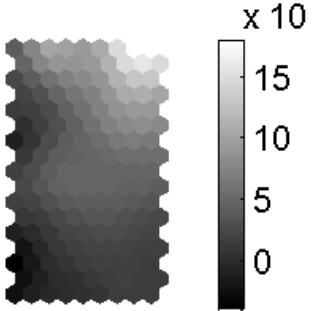

tase
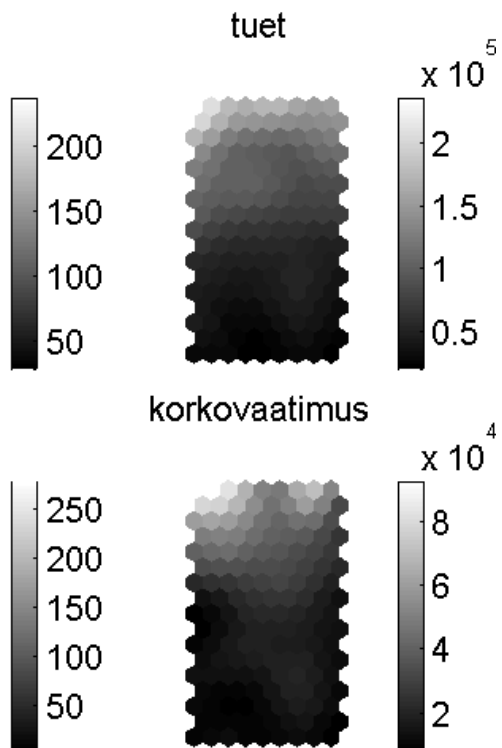

korkovaatimus

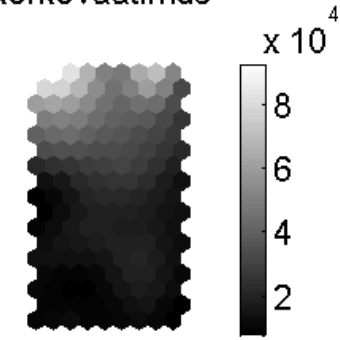

kannattavuuskerroin $\times 10$

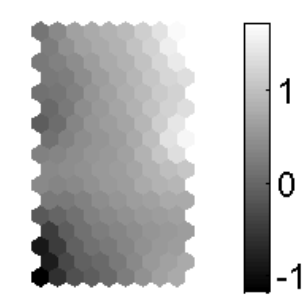

oma pääoma

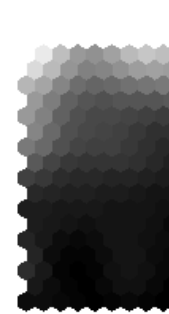

$\times 10^{6}$

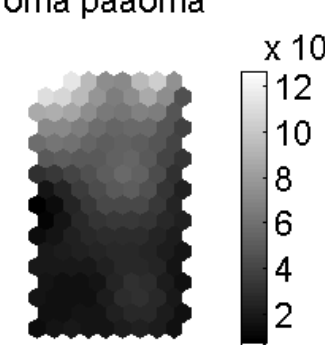

velkarasite

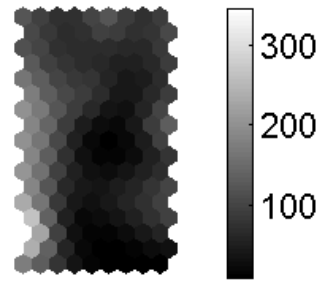

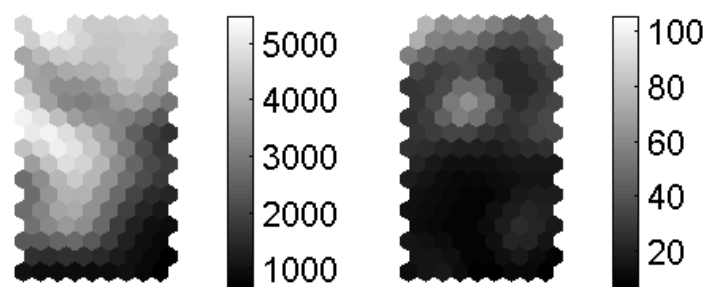

Kuva 2. Kannattavuuskirjanpitoaineistolla opetetun SOM:n U-matriisi ja komponenttitasot. Vaalea harmaasävy merkitsee komponenttitasoilla suurta muuttujan arvoa ja U-matriisilla suurta etäisyyttä. Yksittäinen tila sijaitsee aina kartan samassa kohdassa kaikilla komponenttitasoilla. 


\section{ryhmät}

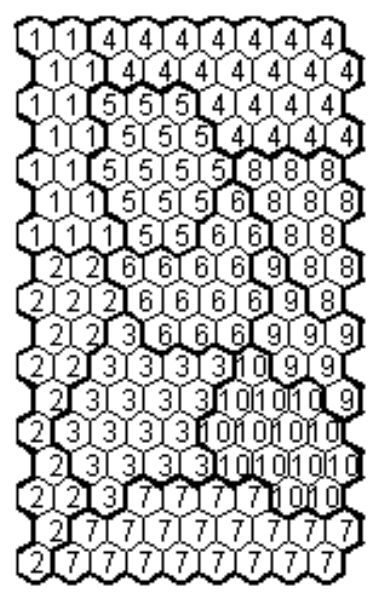

tuotantosuunta

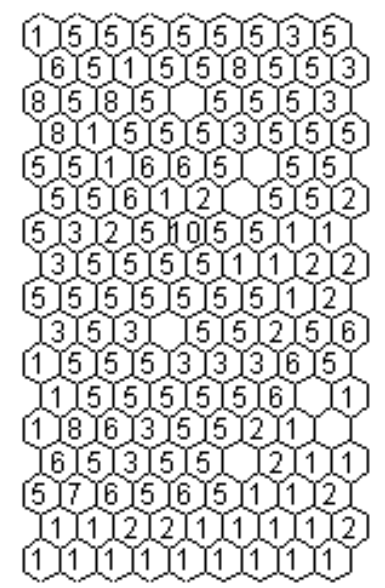

tukialue

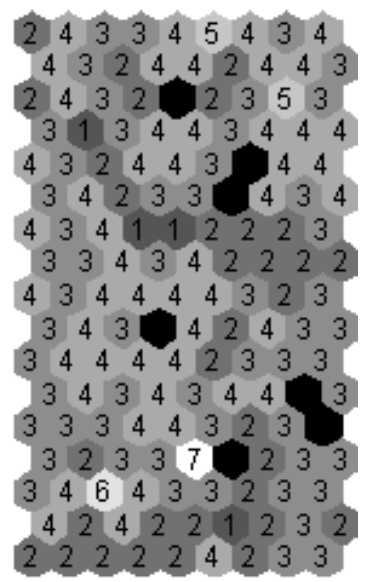

Kuva 3. Ryhmät sekä SOM:n opetuksessa käyttämättömien muuttujien komponenttitasot. Tuotantosuunnan arvot viittaavat kunkin karttayksikön yleisimpään tuotantosuuntaan. Tukialueen arvot ja harmaasävyt viittaavat karttayksikön tukialueen mediaaniarvoon.

Ryhmät 1 ja 4 edustavat suuria tiloja, joilla on suuri viljelyala. Näiden ryhmien pääero on tuotoissa: ryhmässä 1 tuotot ja kannattavuuskerroin ovat matalat, kun taas ryhmässä 4 tuotot ja kannattavuuskerroin ovat korkeat. Toinen ero löytyy velkarasitteista. Hyvin kannattavilla suurilla tiloilla on pienempi velkarasite kuin vähemmän kannattavilla suurilla tiloilla.

Ryhmä 2 koostuu keskikokoisista tiloista, joilla on matalimmat omavaraisuusasteet ja kannattavuuskertoimet sekä korkeimmat velkarasitteet. Tähän ryhmään kuuluvien tilojen kohdalla siis suurten velkojen ja pienen oman pääoman yhdistelmä yhdistyy usein huonoon kannattavuuteen.

Tilat, joilla on pienimmät viljelyalat löytyvät ryhmistä 3 ja 7. Myös taseet ja kannattavuuskertoimet ovat erittäin pieniä näihin ryhmiin kuuluvilla tiloilla. Ryhmällä 3 on kaikkein matalin keskimääräinen kokonaispääoman tuotto. Ryhmän 3 tiloilla työtuntien määrä on suuri suhteutettuna taloudelliseen kokoon. Tähän ryhmään kuuluvien tilojen tuotantosuunta on useammin kasvihuonetila kuin muihin ryhmiin kuuluvilla tiloilla. Ryhmän 7 keskimääräinen taloudellinen koko ja velkarasite ovat hyvin pieniä. Lisäksi ryhmässä tehdään vähän työtunteja ja eläinyksiköitä ei ole juuri lainkaan. Tässä ryhmässä tuotantosuuntien jakauma on hyvin erilainen muihin ryhmiin verrattuna: ryhmän selvästi yleisin tuotantosuunta on viljanviljely ja koko aineiston suurimman tuotantosuunnan lypsykarjatilojen edustajia on hyvin vähän. Näiden kahden ryhmän välillä on selvä ero korkoprosenteissa. Ryhmän 3 yritykset ovat suuremman korkoprosentin perusteella riskialttiimpia kuin ryhmän 7 yritykset.

Ryhmään 5 kuuluvat tilat ovat taloudelliselta kooltaan pienempiä kuin ryhmien 1 ja 4 tilat, mutta viljelyala ja erityisesti vuokrattu viljelyala on tämän ryhmän tiloilla korkea. Korkoprosentit ovat tässä ryhmässä korkeita, mutta muiden muuttujien suhteen ryhmän tilat ovat keskitasoa. Muut nautakarjatilat ja sekamuotoisen tuotannon tilat ovat yleisempiä ryhmässä 5 kuin muissa ryhmissä.

Ryhmää 6 määrittävät matalat korkoprosentit ja velkarasitteet, lyhyet vieraan pääoman takaisinmaksuajat ja erittäin korkeat omavaraisuusasteet. Lypsykarjatilat on koko otoksen yleisin tuotantosuunta, mutta tässä ryhmässä lypsykarjatilat ovat vieläkin yleisempiä.

Kaikkein kannattavimmat tilat ovat ryhmässä 8 . Viljelyalat ovat suurempia ja työtunteja vähemmän kuin muissa saman kokoluokan ryhmissä. Vieraan pääoman takaisinmaksuajat ovat kuitenkin hyvin pitkiä tässä ryhmässä. Tämän ryhmän tilat luokitellaan muita ryhmiä useammin tuotantosuuntaan muu kasvinviljely.

Ryhmä 9 on monessa suhteessa samankaltainen ryhmän 8 kanssa. Tärkeimpinä eroina ovat pienemmät arvot joissain muuttujissa kuten kannattavuuskertoimessa, taloudellisessa koossa ja viljelyaloissa. Ryhmän 9 tavoin myös ryhmä 10 edustaa pieniä tiloja. Lypsykarjatilat ovat harvinaisempia ryhmissä 9 ja 10 kuin muussa aineistossa. Kannattavuus on ryhmässä 10 jonkin verran huonompi, mutta korkoprosentit selvästi korkeammat - itse asiassa korkeimmat kaikista ryhmistä. Toisaalta vieraan pääoman takaisinmaksuajat ovat lyhyet ryhmän 10 tiloilla. 


\section{Johtopäätökset}

Itseorganisoivan kartan käyttö mahdollisti tässä työssä Suomen maatalousyrityksiä vuonna 2010 kuvaavien taloudellisen aineiston tehokkaan analyysin. Tuotetun kartan ja ryvästyksen avulla pystyttiin erottamaan helposti erilaisia maataloustyyppejä. Lisäksi eri muuttujien välisistä yhteyksistä saatiin uutta tietoa. Itseorganisoivan kartan avulla on helppo tuottaa hypoteeseja jatkotutkimusta varten. Muutamaa tällä tavalla tuotettua hypoteesia on testattu viimeaikaisessa tutkimuksessamme (Sulkava ym., 2013), ja tilastollisesti merkitseviä yhteyksiä on löytynyt.

Ryvästysanalyysi tuotti 10 maatilaryhmää. Tuotantosuunnat - erityisesti lypsykarjatilat, viljanviljelytilat ja muut kasvinviljelytilat - jakautuivat ryhmiin eri tavoilla. Ryvästys ei kuitenkaan erotellut tuotantosuuntia omiin ryhmiinsä, vaan muut tekijät olivat tärkeämpiä erottelevia tekijöitä. Ryvästyksen avulla löydettiin useita moniulotteisia yhteyksiä tutkittujen muuttujien välillä. Esimerkiksi keskikokoisten tilojen kohdalla korkeimmat kannattavuuskertoimet ovat kytköksissä suhteellisen suureen viljelyalaan sekä pieneen työtuntien määrän. Toisaalta pääasiallinen ero hyvin ja huonosti kannattavien suurten tilojen välillä on se, että ensin mainituilla on selvästi vähemmän velkaa.

SOM:n ryvästyksellä löydetyt taloudelliset profiilit ovat hyvä pohja Suomen maatalouden suorituskyvyn paremmalle ymmärtämiselle. Muuttujien välisten yhteyksien tarkempi mallintaminen (vrt. esim. Sulkava ym., 2006) ja tilojen kannattavuuden ajallisen kehityksen tutkiminen ovat tulevia tutkimusaiheita.

\section{Kirjallisuus}

Community Committee for the Farm Accountancy Data Network, 2009. Typology handbook, Tech. Rep. RI/CC 1500 rev. 3, European Commission - Directorate-General for Agriculture and Rural Development.

Kaski, S., Kangas, J., Kohonen, T. 1998. Bibliography of self-organizing map (SOM) papers: 1981-1997. Neural Computing Surveys 1:102-350.

T. Kohonen, 2001. Self-Organizing Maps, 3rd Edition, Vol. 30 of Springer Series in Information Sciences.

Latukka, A. 1998. Maatalousyritysten tulorahoituksen riittävyyden ennustaminen neuroverkkomenetelmällä, lisensiaatintutkimus, Helsingin yliopisto, Taloustieteen laitos, Julkaisuja nro 22, Maatalouden liiketaloustiede.

Oja, M., Kaski, S., Kohonen, T. 2003. Bibliography of self-organizing map (SOM) papers: 1998-2001 addendum. Neural Computing Surveys 3:1-156.

Rantala, O., Tauriainen, J. 2013. Maatalous- ja puutarhayritysten tulos- ja kannattavuuskehitys. Teoksessa: J. Niemi ja J. Ahlstedt (toim.) Suomen maatalous ja maaseutuelinkeinot 2013, sivut 56-60.

Sulkava, M., Sepponen, A-M., Yli-Heikkilä, M., Latukka, A. 2013. Clustering of the self-organizing map reveals profiles of farm profitability and upscaling weights. Neurocomputing. Hyväksytty julkaistavaksi.

Sulkava, M., Tikka, J., Hollmén, J. 2006. Sparse regression for analyzing the development of foliar nutrient concentrations in coniferous trees, Ecological Modelling 191 (1):118-130.

Sulkava, M., Yli-Heikkilä, M., Latukka, A. 2012. Analysis of farm profitability and the weighted upscaling system using the self-organizing map. Teoksessa: P. A. Estévez, J. C. Principe ja P. Zegers (toim.), Advances in Self-Organizing Maps: 9th International Workshop, WSOM 2012, Proceedings, Vol. 198 of Advances in Intelligent Systems and Computing, Springer, sivut 285-294.

Ultsch, A., Siemon, H. P. 1990. Kohonen's self organizing feature maps for exploratory data analysis. Teoksessa: INNC 90 Paris - International Neural Network Conference, Kluwer, sivut 305-308.

Vesanto, J., Sulkava, M. 2002. Distance matrix based clustering of the self-organizing map. Teoksessa: J. R. Dorronsoro (toim.), Artificial Neural Networks - ICANN 2002: International Conference, Proceedings, Vol. 2415 of Lecture Notes in Computer Science, Springer-Verlag, sivut 951-956. 